\title{
Scottish Women and the Hangman's Noose
}

This study has thus far provided chapters examining the place of capital punishment within the Scottish criminal justice system and has explored three key periods in Scotland's use of the death sentence between 1740 and 1834. Although Scottish women were among the numbers sent to the scaffold in each of these periods, they accounted for less than one in ten of the total offenders executed overall. However, this chapter will demonstrate that a study of the Scottish women who did receive a capital punishment can enhance not only the field of eighteenth and nineteenthcentury Scottish criminal history but can also provide a fresh perspective from which to view the Scottish female experience in this period.

Within the historiography focused upon women in Scotland in this period, some studies have highlighted their crucial contribution to Scotland's industrial development. ${ }^{1}$ In addition, Mitchison and Leneman provided studies of sexuality and social control, in rural and urban Scotland respectively, between the mid-seventeenth and late eighteenth centuries that have included analyses of attitudes towards illegitimacy. ${ }^{2}$ More recently, the edited collection Gender in Scottish History since 1700 offered an analysis of key aspects of Scottish history, including identity, employment, religion and culture from a previously limited female perspective. ${ }^{3}$ In terms of women and Scotland's penal history, there have been numerous works dedicated to the witch-hunt in Scotland that have described the distinct Scottish experience of this European phenomenon. ${ }^{4}$ In addition, despite the dearth in studies of capital punishment, Kilday provided a pioneering work focused upon women and the

(C) The Author(s) 2018

R.E. Bennett, Capital Punishment and the Criminal Corpse in Scotland, 1740-1834, Palgrave Historical Studies in the Criminal Corpse and its Afterlife, https://doi.org/10.1007/978-3-319-62018-3_4 
commission of violent crimes in Lowland Scotland between 1750 and 1815. Infanticide has also been examined, with Kilday in particular having worked extensively upon the crime in Scotland and its place within the wider British narrative. ${ }^{6}$ However, the current chapter will provide the first study dedicated to examining the implementation of capital punishment against women in Scotland, including an analysis of the types of offences that led women to the scaffold and an exploration of the varied responses to female perpetrators in the courts and in public discourse.

There were a range of penal options available to the Justiciary Court judges in eighteenth- and nineteenth-century Scotland to punish convicted female offenders. Like Scottish men, women could face the most serious punishment, the death sentence, as well as punishments that removed them from the realm, namely transportation and banishment from Scotland, as well as prison sentences and corporal punishments. Between 1740 and 1834, a total of 79 women were capitally convicted in Scotland, of whom 47 (59\%) were executed and 32 (41\%) were subsequently pardoned. Of the total number of 505 executions in Scotland between 1740 and 1834 , these 47 condemned women made up $9.3 \%$ of the total offenders who met their fate upon the scaffold. This figure is comparable to those presented for England and thus it reinforces the broad argument that women made up a low proportion of the total offenders who suffered a capital punishment in Britain. ${ }^{7}$ Therefore, it is not surprising that several years could separate the executions of women in Scotland. For example, there were no women executed in Scotland for 15 years between 1793 and 1808. In some circuit cities, the occurrence was even rarer, a fact that was often noted by contemporary newspapers.

This book dedicates a chapter to examining the women who faced the hangman's noose for two key reasons. First, the structure adopted thus far has allowed for an expansive survey of the use of capital punishment in Scotland and a closer examination of three key periods in the use of the death sentence. Although women were among those sent to the gallows, their low numbers and the fact that the executions were relatively spread out over the period provided limited scope for any substantial analysis of their experience. Second, a specific investigation of the cases of the women who received a death sentence provides an opportunity to glean details about wider responses to female criminality. As Walker suggested, the concept of gender can be employed as an analytical tool to provide historians with an insight into the role of women in both the domestic setting and in the wider community. ${ }^{8}$ Through a close reading of the available material on individual cases, the chapter will adopt a primarily qualitative analytical 
approach when examining the types of offences that sent women to the scaffold, and the legal and lay responses to them across the period.

The central argument to be made here is that, like the treatment of male criminals, the Scottish criminal justice system exercised a large degree of discretion when deciding upon the punishments to be meted out to the women brought before their main judicial courts. Scottish women were not given "escalated and aggravated punishments for their crimes in comparison to their male criminal counterparts" as has been suggested. ${ }^{9}$ Instead, the death sentence accounted for about $4 \%$ of all punishments meted out to women by the High Court and the three circuit courts in Scotland in this period. ${ }^{10}$ However, despite the low overall number of executions, the chapter will demonstrate that the Scottish courts were prepared to exercise the full weight of the law where it was deemed necessary due to the circumstances surrounding individual cases.

To enhance this argument the chapter will be structured as follows. It will first investigate the women capitally convicted for the crime of homicide. From a reading of the valuable information offered in the court records and in the newspapers, it will examine the importance of the victim, and the motive and method of killing in shaping responses to these women. The second section will provide an in-depth exploration of the crime of infanticide as, in over two thirds of the total homicide cases that resulted in a capital conviction, the victim was the woman's own child. Again, the crime has gender-specific resonances and an exploration of these cases can be used as a lens into wider issues surrounding motherhood and illegitimacy. The third and final section of the chapter will provide an examination of the punishment of women convicted for property offences in this period. It will highlight that the Scottish courts exercised a great degree of discretion when deciding upon the types of punishments to be handed down and that only a small proportion of the women who were charged and convicted by the courts of a potentially capital property crime were subsequently given the death sentence. However, in the small number of cases that did result in an execution, it is possible to discern particular factors that led certain women to the scaffold, notably if they were repeat offenders.

\section{HOMICIDE}

The crime of homicide has long been set apart within the annals of penal history. Among the black catalogue of crimes that led criminals to the scaffold in the eighteenth and nineteenth centuries, homicide required an exemplary judicial response due to the fear and revulsion surrounding 
the commission of the offence. An examination of the legal responses to those found guilty of the crime is crucial to this study of capital punishment as vital information can be gleaned about not only the implementation of the death sentence, but also how the courts viewed the role of the public execution in providing a stark and exemplary demonstration of the criminal justice system's response to homicide. It is the intention here to question these things in relation to the murderous Scottish women who met their fate at the end of the hangman's rope. Of the total 47 women executed across this period, 36 had been convicted of murder. In 23 of these cases the victim had been their own child. The crime of child murder, often also referred to as infanticide, whilst a form of homicide punishable by death, was treated with some distinction and is thus extensively analysed in the next section. However, the chapter will first examine the cases of the remaining 13 women executed for murder, including an investigation of their victims and the method of killing and how these things impacted upon their treatment in the courts. Contemporary responses to these crimes were often shaped by the fact that the perpetrators were female and, in some instances, it was not solely the motives or violence employed in the murders that caused the greatest consternation, but shock at the fact that a woman had been capable of such a crime at all.

Kilday highlighted that in $88 \%$ of cases where women were indicted for homicide, the victim was a relation or someone close to the accused, compared with a figure of only $27 \%$ for men. ${ }^{11}$ The figures for those capitally convicted and executed for murder broadly reinforce this finding, as in $41 \%$ of male murder cases the victim was a family member, predominantly their wife or a lover, and the remaining $59 \%$ of cases were made up of murders that occurred during the commission of property offences or disputes, often drunken ones, between work colleagues and strangers. Comparatively, of the 36 women executed for murder, there were only five cases where the victim was a stranger to them. Of the remaining cases, 23 women had been convicted of infanticide, or child murder, four had murdered their husbands and four had murdered other family members including siblings and in-laws. An in-depth exploration of these women, including their motivations for murder and their chosen methods of killing, highlights a fresh and valuable perspective of the domestic life of some Scottish women across this period. It provides a different angle from which to view the eighteenth- and nineteenth-century wife and mother and, crucially, reveals the varied responses to women who violated these roles through murder. 
In 1754 Nicholas Cockburn was executed in Edinburgh for the murder of her husband James Kid and her step-mother Susan Craig after she laced their porridge with arsenic. Neighbours had told the court that Nicholas and her husband "did not live well together as man and wife ought to" and on the day of his death she had shown no "natural concern." Similarly, Nicholas was described as harbouring ill feeling towards Susan due to her belief that she would obtain her father's money upon his death. Although she had not initially been suspected of her husband's murder, when the cause of Susan's death was discovered her neighbours raised their suspicions due to the couple's strained relationship and a quantity of arsenic was discovered in her home. ${ }^{12}$ When addressing Nicholas to sentence her to death and order that her body would be sent for dissection as per the stipulations of the Murder Act, the Lord Justice Clerk lamented the shocking nature of the crime. He noted that the punishment she received was a mild one in comparison to those inflicted upon offenders in other countries. ${ }^{13} \mathrm{He}$ was likely referring to the fact that in England the crime of a wife murdering her husband was categorised as a form of petty treason punishable by burning at the stake. The executions were often mitigated in practice by the second half of the eighteenth century as the executioner could strangle the women before they were burnt, although there were examples where this did not happen. This form of punishment was not formally abolished until 1790. ${ }^{14}$ Despite the extension of the English laws regarding full treason to Scotland in 1708 ( 7 Ann c.21), the crime of petty treason was not extended north of the border. However, a reading of the responses to Scottish women who murdered their husbands, such as that above, reveals a specific abhorrence for the offence, even compared to other forms of homicide.

Margaret Shuttleworth and her husband Henry had been married for 15 years and ran the Hope Inn in Montrose but accounts of their volatile relationship offered to the court during her trial for his murder highlighted Margaret's neglect of her expected duties as a wife. She was accused of being regularly drunk and "outrageous with her tongue", often cursing and swearing at her husband. On the night of Henry's death, Margaret had rushed to a neighbour's house crying that he had been murdered. He was found to have been struck on the head with a poker. In the court, Margaret maintained her plea of innocence and claimed that any number of people could have committed the crime as it was a market day and there were many people passing through the inn. When the Advocate Depute addressed the 
jury he acknowledged the circumstantial nature of some of the evidence but stated that he considered the charge clearly proven due to the proof offered of her previous "outrageous conduct." 15 Despite the lack of the same premeditation to murder that was more prominently apparent in several other cases, in Margaret's case it was upon her deficiencies as an obedient wife that the prosecution had built its strongest case for her conviction of the murder.

In the case of Margaret Cunningham, it was her motive for the crime that the court found the most abhorrent. She had poisoned her husband John Mason with arsenic in their home in Fife so she could continue her extra-marital relationship with a man named John Skinner. Although her execution had to be delayed because she was pregnant, within a month of the birth she appeared at the bar with the new-born child in her arms to hear the judge pass the death sentence. He recommended that she make her peace with God as she had no hope of a reprieve due to her motive for the murder and the premeditation she had employed when carrying it out. ${ }^{16}$ The court's determination to use her case as an example of the reward for murder was made more emphatic because the city of Edinburgh had not witnessed the execution of a woman for 30 years and thus the crowd gathered was immense. ${ }^{17}$

Of the 36 women executed for murder in this period, their victim was a stranger to them in only five $(13.8 \%)$ of the cases. Comparatively, of the 124 men executed for murder, their victim was a stranger to them in at least $50(41 \%)$ of the cases. Despite the evident proportional difference in these figures, when comparing the circumstances in these male and female homicide cases there is a discernible area of comparison: the motive of financial gain. In around half of the cases where men murdered strangers they were also indicted for a property offence such as theft or robbery, and in several others they had owed the deceased money which had been the cause of a fatal fight. In four of the five cases where women were executed for the murder of a stranger the crimes had been financially motivated. The case of Helen Torrance and Jean Waldie in 1752 pre-dated the shocking and now infamous Burke and Hare murders of the early nineteenth century but was similarly motivated. They abducted and murdered John Dallas, a boy of eight who lived in their neighbourhood, and sold his body to some medical students. Their defence pointed towards John's previous ill health and the fact that there were no marks of violence on the body, but their attempts to cast doubt on whether he had been murdered or had died of natural causes failed. The prosecution's case, that they had stolen a living child 
and sold a dead body to the medical students, was enough to remove any doubts over their guilt and to capitally convict the two women. ${ }^{18}$

The case of Mary McKinnon is noteworthy here as it was the only one, of the total five women executed for the murder of a stranger, that was not financially motivated, nor was there evidence of any premeditation. However, the circumstances surrounding both her profession and her place within the wider community were key factors that prompted the court to pass the death sentence. She was a brothel keeper on South Bridge Street in Edinburgh and on the night in question the deceased had visited with a group of men when a scuffle broke out. Mary had attempted to intervene between one of the girls and William Howatt when he grabbed her by the hair and she reached for a nearby knife and stabbed him, inflicting what proved to be a fatal injury. On the day of her trial the courtroom was full and, outside, Parliament Square and the High Street were thronged with people waiting to hear the details of the case which lasted for over 18 hours. ${ }^{19}$ She was found guilty by a plurality of voices by the jury but recommended mercy. However, in pronouncing the death sentence, the judge advised her to prepare for the day of her execution as he could see no reason why mercy would prevail. ${ }^{20}$

Mary's case is interesting as there was clearly an argument to be made for self-defence or a restriction of the murder charge to the lesser, and non-capital, charge of culpable homicide. This had been the case in numerous similar instances; for example, in cases brought before the Justiciary Court where fatal wounds had been inflicted during fights between male perpetrators and their victims. In addition, she was not unanimously found guilty but, due to the Scottish practice where only a majority verdict was required by the jury, she was convicted. Furthermore, although she had been recommended mercy by the jury, there is no correspondence within the Home Office pardoning records to suggest that the judges endorsed this recommendation and, as has previously been argued, the opinion of the judges was often taken into serious consideration when deciding whether to pardon capitally convicted offenders. Evidence of the determination to send her to the scaffold is also clear if we consider that, in the period between 1740 and 1834, a total of 26 men were pardoned for murder and 16 of the cases had similarities with Mary's in that the deaths had occurred because of wounds inflicted during fights and lacked the premeditation to murder. However, the fact that the same pardon was not extended to Mary was likely more related to her position as a brothel keeper and the public interest in the case this had caused, rather than the circumstances surrounding the murder itself. 
When analysing female criminality, Kilday argued that the Scottish women who used violence in the commission of their crime were subject to greater censure by the courts due to their straying from their more traditional and domestic contemporary roles. ${ }^{21}$ This chapter will now seek to enhance our understanding of the legal and press responses to women and the commission of violent crime through an analysis of the methods of killing utilised by the 13 women executed for murder in this period. In seven of the cases the women had poisoned their victims, arsenic was used on four occasions. It was a relatively accessible substance as it was regularly used in households to combat vermin. In the case of Nicholas Cockburn, her use of arsenic to poison both her husband and her stepmother had prompted a national debate over the availability of the substance. When lamenting the case the judges at the Southern Circuit ordered the local sheriffs to implement the stricter sale of arsenic in order to combat its use for poisoning which was referred to as a "major public concern." 22 When Catherine Davidson poisoned her husband, an article detailing the murder in the Caledonian Mercury found particular concern in the fact that she had mixed sulphuric acid with whisky in order to pour it down her husband's throat while he slept. ${ }^{23}$ In cases of poisoning, the women had not only committed a murder but they had also tapped into the recurring contemporary fear that poisoning was a difficult crime to guard against, particularly in the domestic space, and it fundamentally violated the trust, or at least wifely deference, in a marital relationship.

Of the remaining six cases, two women had suffocated their victim and another had stabbed the deceased, but there were three in which more overt violence was used. In the case of Margaret Shuttleworth, discussed above, she had hit her husband on the head with a poker, perhaps during an altercation. However, the cases of Margaret Adams and Christian McKenzie respectively provide a reinforcement of Kilday's assessment that "fatally violent women in Scotland were not to be forgiven, understood or sympathised with." 24 Indeed, due to the rarity of such violent cases involving women, they were believed to be almost beyond comprehension. When Christian McKenzie was indicted at the Inverness Circuit Court in September 1764 for the murder of her brother-in-law and her mother-in-law her defence stated to the court that "the crimes are so shocking in nature that it would be impossible for any person, especially the panel who is but a woman of 19, to commit such barbarity." 25 She had often quarrelled with Mary Taylor, her mother-in-law, and one day she violently attacked her on the road 
outside Inverness. Mary had cuts to her face and several other wounds when her body was discovered. Christian had also smothered 13-yearold Kenneth, her brother-in-law, as he had discovered her crime and intended to raise the alarm. ${ }^{26}$

Margaret Adams, age 22, had been convicted along with her sister Agnes, age 16, for the murder of shopkeeper Janet McIntyre. In the court their defence labelled the crime as too horrid in nature and the details of the murder as being too incredible to have been committed by women. ${ }^{27}$ The sisters had entered Janet's shop on Argyle Street in Glasgow and violently beat her about the face and head with a brickbat and strangled her with a handkerchief, after which they plundered the shop for money. Although they were both capitally convicted, Margaret, as the principal offender, was executed while Agnes was conditionally pardoned. ${ }^{28}$ Due to the violence involved in the case it was extensively detailed in the Scottish newspapers and received substantially more coverage in several English newspapers than other Scottish murders. Therefore, the case supports King's argument that female murderers were often given around double the average coverage afforded to other offenders in the late eighteenth-century press. ${ }^{29}$

\section{INFANTICIDE}

Within the annals of female criminality in the eighteenth and nineteenth centuries the crime of child murder, or infanticide, has featured prominently due to its gender-specific connotations as, in most cases, the perpetrator was the mother. ${ }^{30}$ The current chapter will further this body of work by situating a study of infanticide within its broader analysis of Scotland's use of capital punishment. It will explore the motives of the women who committed the crime and the methods they employed to carry it out and how these things impacted upon their treatment in the courts. In addition, as child murder accounted for an overwhelming majority of the total number of women tried for murder before the courts, this study offers a unique insight into the punishment of women in this period. In terms of the wider aim of this book, namely to chart the changing use and implementation of capital punishment in Scotland between 1740 and 1834, the crime of infanticide is an important area of analysis as this period witnessed a gradual shift in judicial responses towards it. The central argument here is that, although the crime of child murder sent more Scottish women to the scaffold than any other 
offence, the Scottish courts exercised a great degree of discretion when sentencing offenders and, of the total number of women who received some form of punishment for the crime, in only $13 \%$ of cases was a capital punishment handed down.

The theme of illegitimacy as a motive is pervasive in studies of infanticide and this is reflected in the fact that, of the 23 women executed for the crime, their victim was an illegitimate child in all but one of the cases. The 1690 Scottish 'Act Anent Murthering of Children' directed juries to capitally convict women who had concealed their pregnancy and the birth of an illegitimate infant that had subsequently died, with or without direct evidence of murder. Its provisions mirrored those of the 1624 statute in England, namely that the onus was upon the mother to prove her innocence of the crime and that the child had been born dead. Symonds advised that the statute "marked both public awareness of infanticide and a new will to govern resolutely, for it forced jurors to presume guilt...even when they were shown no direct evidence of murder." 31 While illegitimacy itself carried a social stigma, a reading of the motives of the women who murdered their infants reveals that it had broader implications.

Examining the biographical information offered to the courts, it is evident that at least 14 of the 22 women executed for the murder of their illegitimate child worked in some form of domestic service. Young and unmarried domestic servants fit the archetypal profile of many of the women brought before Britain's criminal courts for the crime of child murder. ${ }^{32}$ They were of childbearing age, often lived in close proximity to men and, crucially, their employment required that they remain single and childless and thus an illegitimate infant could mean a loss of reputation for an employer and a dismissal without a reference for the mother. ${ }^{33}$ The prominence of these women in the court records may be explained by the fact that they were more likely to be caught due to the close proximity of their living quarters to their employer or other members of staff and the general difficulty of concealing the birth and the death of an infant. In some cases the statute was considered particularly relevant as the women concerned were suspected of being with child but had denied it. One example is Katharine Ross, whose repeated denials of being pregnant to both her employer and fellow servants and her giving birth in a dunghill near her place of employment without calling for assistance removed any doubt in the minds of the court that she had intended to murder her child. ${ }^{34}$ 
Despite its negative implications for the unmarried domestic servant in this period, the bearing of an illegitimate child did not drive all women to commit the crime of infanticide. Symonds estimated that illegitimate births accounted for at least $5 \%$, likely more, of the total births in Scotland between the late seventeenth and eighteenth centuries. ${ }^{35}$ At the start of civil registration in 1855 , illegitimate births accounted for $9.1 \%$ of the total. ${ }^{36}$ Although in 22 of the total 23 child murder cases women had murdered their illegitimate children, in some cases it was not necessarily the status of having an illegitimate child that was their primary motive, but the financial implications. Anne Mackie was a widow with four children from her marriage when she began a relationship with a younger man named James Gray. However, when she revealed her pregnancy to him he refused to marry her and she strangled the child at birth. ${ }^{37}$ Agnes McCallum had given birth to an illegitimate infant at the age of 16 but the child was left in the care of the father in Greenock when she moved to Paisley to work as a bleacher. At the age of 30 she had given birth to another child but in this case the father was a married man. When the infant was five months old she had asked him for more money to pay for a nurse and when he refused she poisoned the child with vitriol. The Caledonian Mercury observed that, prior to the murder, Agnes had showed "all the tender feelings of a mother" until circumstances had driven her to commit the crime. ${ }^{38}$ Combined with the fact that Agnes had another living illegitimate child, this is further evidence that, in some of these cases, illegitimacy alone was not a motive for murder if arrangements could be made to adequately care for the child. In Agnes' case the financial implications of having no male support were crucial in her motive for the murder.

Despite their capital conviction before the courts, there was some evident consideration of, if not sympathy for, the circumstances that had led the women who murdered their children to the scaffold. Reporting on the case of Margaret Gillespie in 1749, the Scots Magazine recounted her version of events in which she had been ravished against her will and deserted by a married man. ${ }^{39}$ The coverage afforded to the case was extensive compared to other murder cases in the Scottish press in the mid-eighteenth century, perhaps demonstrating how her case had captured the public's interest, if not even sympathy. Barbara Malcolm was executed in Edinburgh in 1808 for the murder of her 18-month old daughter Margaret and was the last woman executed for child murder in Scotland in the period under investigation here. A reading of the 
press coverage of her case can enhance our understanding of the varied responses to women who murdered their children as, despite an evident abhorrence for the method in which she had murdered the child, there was also some consideration given to the circumstances that had forced her to it. Following the birth of her illegitimate daughter, Barbara had paid another woman to nurse the child. However, when the woman's own child was fully weaned she could no longer care for Margaret and Barbara found herself unable to work to support herself and the infant. After two unsuccessful appeals to Margaret's father she poisoned the child with vitriol and medical witnesses attested to the court that she would have died "in excruciating torture." 40 Despite strongly condemning the murder itself, one article described how Barbara was a mild tempered and caring mother until the rejection of the child's father had driven her to commit the awful crime through desperation. ${ }^{41}$ In addition, a report of her execution described a solemn scene in which she was so feeble with grief that she needed support to mount the scaffold. ${ }^{42}$ These accounts highlight that, although the case had been clearly proven and there were no questions raised over the justice of her sentence, there was at least some contemporary awareness, or even understanding, of the circumstances that had conspired to force Barbara to kill her child.

Among the black catalogue of murders that had sent Scottish criminals, both men and women, to the scaffold, the case of Agnes Dugald stands out in terms of both motive and method. Of the 23 women executed for the murder of their children, 18 involved a new-born infant and in a further four the child was aged between one month and 18 months old. ${ }^{43}$ However, Agnes Dugald was indicted for the murder of her 8-yearold daughter Joanna. In addition, her case provides the only example of a mother being executed for the murder of her legitimate child in this period as Joanna was the daughter of Agnes' late husband who had died a few years earlier. ${ }^{44}$ She had previously cared for the child but became resolved to murder her when she began cohabiting with a man who had promised that he would marry her if Joanna was removed from their lives. On the day of the murder Agnes concealed a knife under her apron when she took Joanna out for a walk by the river. When they approached a dense woodland area, she seized her and threw her to the ground. There were defence wounds on the child's hands where she had attempted to defend herself from the blade but Agnes succeeded in cutting her throat so violently that she almost severed the head from the body entirely. ${ }^{45}$ The case attracted national attention and, in his 1829 
edition of The Annals of Glasgow, James Cleland captured the public's revulsion when he described Agnes as an "atrocious woman [who] had lived a very lewd and wicked life" to the detriment of her unfortunate child. ${ }^{46}$

The case of Agnes Dugald certainly provides a reinforcement of Kilday's assessment that some Scottish women employed "unusually bloodthirsty methods" when committing the crime of murder. ${ }^{47}$ Furthermore, this study has found that in eight of the 23 cases where women were executed for infanticide they had employed violent methods to carry out the crime including strangulation, stabbing and beating. This figure is higher if we also include the three women who suffocated their infants, the two cases where the child died in agony due to the use of poison and the four cases of drowning. Therefore, the study reinforces the argument that some Scottish child murderers were not averse to the use of violence. ${ }^{48}$ However, a closer reading of the details in individual cases highlights that there were different degrees of violence used that we need to examine. For example, in 1759 surgeons attested that Ann Morrison's child met a violent death due to the multiple cuts and bruises found upon the body. ${ }^{49}$ In 1761 Christian Munro cut her child's body into pieces and it was only when one hand was discovered on her employer's land that she was apprehended for the crime. ${ }^{50}$ Comparatively, despite the fact that a knife wound had been discovered on the neck of Janet Clerk's infant in 1754, the defence argued that she had been trying to cut the navel cord wrapped around the child's neck and had accidentally inflicted the wound. However, the fact that she had concealed the birth and disposed of the body in a dyke convinced the jury of her guilt..$^{51}$

As many of the women executed for child murder in this period were either domestic servants or lived in close proximity to others in lodging houses, the concealment of their pregnancy and the birth of the child could be quite difficult and this study has found that these factors impacted upon the methods of killing used. For example, Christian Fren had feigned illness to her mistress and retired to her bedroom but when she later went to check on her she could smell a "nauseous burning." Christian had given birth in secret and had thrown the child into the hearth. Although she claimed the child was born dead she was convicted due to her attempts to conceal all evidence that she had given birth. ${ }^{52}$ In previous studies of child murder, historians have pointed towards suffocation or exposure as primary methods of killing. ${ }^{53}$ This analysis provides some support for these findings as three women 
suffocated their infants and there were six cases in which there were no marks of violence upon the bodies and no clear indication of the cause of death beyond neglect following birth. In these cases, the methods of killing were explicitly linked to the primary motive of concealment. The locations at which the women had given birth, and at which the bodies were later found, including a park, a field and even a dunghill, were key as they afforded privacy. They also provided a means to either expose the child to the elements or to conceal the bodies of infants who had perhaps died during birth which would explain the lack of any discernible marks of violence. ${ }^{54}$ Despite the obvious motive of concealing the birth, these women did not show the same level of pre-meditated malice that was believed to be evident in cases such as Agnes Dugald's or in poisoning cases.

In an examination of illegitimacy rates in Scotland, Mitchison and Leneman showed that, although there were small fluctuations including a slight peak in the 1740s, the level of illegitimacy in Scotland was no higher in the 1770s than it had been in the 1730s. ${ }^{55}$ However, when charting the indictment and conviction rates for infanticide in Scotland between 1700 and 1799, Kilday demonstrated that there was an increase in the number of indictments beginning in the mid-eighteenth century which peaked in the late 1760 s before declining. She added that the increase may be attributed to a combination of an increased sensitivity to illegitimacy and a reaction to a perceived increase in the commission of the crime of child murder. ${ }^{56}$ This rise in the sheer number of women brought before the central criminal courts in the mid-eighteenth century may also be linked to an increase in the control exercised by the central courts in the wake of the 1747 Heritable Jurisdictions Act, particularly in northern Scotland. This study has shown that the volume of business brought before the Northern Circuit was greater than elsewhere in the country in the mid-eighteenth century, even the High Court in Edinburgh, although punishing the crime of child murder did not prompt the same urgency evident in the suppression of the other offences discussed in Chap. 3. However, contextually, the wider determination to impose centrally driven justice in the area was perhaps symptomatic in the Northern Circuit accounting for a sizeable proportion of executions for child murder in this period.

The chronology of the 23 executions for child murder reflects this pattern as 19 of the cases occurred between 1740 and 1767, with ten following trials before the Northern Circuit. Again, the victims in all 
but one of these cases were illegitimate infants and the perpetrators were predominantly young, single women often employed in some form of domestic service. However, rather than reflecting an increase in illegitimacy rates and thus the increased need for concealment of birth through murder, this study contends that this concentration of female executions can be placed within the wider context of the peak numbers of executions being carried out in the mid-eighteenth century, particularly in northern Scotland. Despite this, there was also a distinct response to the crime. In May 1762, reporting on the fact that five women had suffered a capital punishment for infanticide since April 1761, the Scots Magazine commented on the "lamentable frequency of child murder and the consequent necessity of endeavouring to put a stop to it." 57 Following this concentration in cases between the 1740s and 1760s, there were only a further four women executed for child murder in the period under investigation here and these cases occurred sporadically, averaging about one per decade, until the final execution in 1808. It is the argument here that, despite the fact that women who committed infanticide made up an overwhelming majority of the total cases of female homicide brought before the courts, the period between the mid-eighteenth and the early nineteenth century was one of transition and development in sentencing practices and punishment for the crime.

Between 1740 and 1809, approximately 250 women received some form of punishment for the crime of child murder. The Concealment of Birth (Scotland) Act (49 Geo III c.14) of 1809 repealed the 1690 statute and stipulated that concealment of birth was an alternative charge to child murder and carried a maximum sentence of two years in prison. Of the 250 women brought before the courts for the offence before 1809 , only 33 (13\%) received a capital conviction which resulted in 23 executions and 10 pardons. Of the total 292 Scottish criminals who had been capitally convicted but pardoned, only 40 (14\%) were convicted murderers. However, when broken down by gender, it is apparent that of the total 50 women capitally convicted for murder, $36(72 \%)$ were executed and $14(28 \%)$ were pardoned. Comparatively, $124(83 \%)$ of the total 150 men capitally convicted for murder were executed and 26 (17\%) were pardoned. Therefore, Kilday's argument that Scottish women in the eighteenth century were given "escalated and aggravated punishments for their crimes in comparison to their male criminal counterparts and were unlikely to be pardoned" is not substantiated by this research, particularly in relation to the crime of child murder. ${ }^{58}$ 
In the majority of the remaining 250 cases where women had received some form of punishment for the crime of child murder, the Scottish legal system had allowed them to petition the courts before the start of their trials. This resulted in most of them being banished from Scotland, and a few being transported, for varying lengths of time including for seven years, 14 years and for life. ${ }^{59}$ In the 20 years immediately before the passing of the 1809 act, 79 women accused of child murder petitioned the court and were banished from Scotland and an additional two were transported. Comparatively, in the same period, there were only three women capitally convicted for the crime with two of them, Agnes McCallum and Barbara Malcolm, subsequently executed. Their cases are detailed above and stand out from other examples of infanticide as their children were months old at the time of the murders and these women were belived to have acted with premeditation rather than through panic or mistake during the birth, as in some other cases.

When Margaret Stewart was brought to trial for the murder of her illegitimate infant in Edinburgh in 1743 the libel described "a chain of circumstances which, when put together, are strong evidence of the actual murder" in line with the provisions of the 1690 statute, namely that she had concealed her pregnancy and the birth of the infant. ${ }^{60}$ However, by the mid-eighteenth century, while the statute was still charged, it increasingly required more justification than concealment of birth alone due to an evident ambivalence on the part of some juries to convict these women of a capital charge. For example, in 1754 Isobel Kilgown was found guilty only of exposure after the body of her dead infant was discovered, even though she had concealed her pregnancy and the birth. She was sentenced to be whipped and banished from Scotland. ${ }^{61}$ Murdo Downie was found guilty of exposure as opposed to murder and received a prison sentence of nine months in $1800 .^{62} \mathrm{It}$ was also increasingly apparent that witnesses who examined the bodies of suspected murder victims were questioned more closely on whether the child had come to full term and whether they appeared healthy. Similarly, in 1777 it was commented that the severe law in England regarding child murder was becoming more mildly interpreted and that some form of presumptive evidence was required to prove that the child was born alive. ${ }^{63}$ Through an analysis of the punishments meted out to women for the crime of infanticide between the mid-eighteenth and the early nineteenth century, this study has identified a gradual shift in judicial responses to women accused of child murder in practice years before the introduction of the Concealment of Birth Act in 1809 that provided 
for alternative charges. It has offered a reinforcement of the wider British experience in terms of the shift in attitudes towards the evidence required to convict these women, whilst also demonstrating the importance of the distinct Scottish pre-trial practice of petitioning in providing the courts with an alternative punishment to the death sentence.

\section{Property Offences}

Of the total 544 Scottish criminals capitally convicted for a property offence in the period under investigation here, only 28 (5\% of the total) were women. Although the numbers were smaller in Scotland, the proportion of capitally convicted female property offenders was comparable to the figures presented for parts of England. ${ }^{64}$ However, this is not to say that Scottish women did not commit property offences. They did. Instead, the argument here is that, an analysis of the punishments meted out to offenders alongside a consideration of the arguments presented in Chap. 2, demonstrates that there was a great degree of discretion exercised by the Scottish courts when dealing with those convicted. As stated above, the death sentence accounted for around $4 \%$ of the total punishments meted out to Scottish women. Transportation accounted for around $49 \%$ of the total and in many of these cases the offenders had been convicted for a property crime which could have potentially carried a capital charge. Other punishments handed down to female property offenders included banishment from Scotland and prison sentences as well as corporal punishments such as whipping and standing upon the pillory prior to the turn of the nineteenth century. Of the total 28 women capitally convicted for a property offence, $11(39 \%)$ were executed and $17(61 \%)$ subsequently pardoned. This compares to 321 men executed $(62 \%)$ of the total 516 men capitally convicted. These figures reinforce the argument that there was not a great contemporary desire to see women hanged for property offences in Scotland.

Of the 11 women executed for a property offence between 1740 and 1834, six were convicted for theft, three for housebreaking and theft, one for wilful fire-raising and one for robbery. In the case of Margaret Crossan, who was executed in Ayr in 1817 for wilful fire-raising, the extent of the damage caused was a deciding factor in the court's decision to pass a capital sentence. She had deliberately set three separate fires on a farm in Wigtown which had the desired effect of completely consuming the farm in flames and killing valuable livestock. The motive was a dispute she had with the tenant farmer. ${ }^{65}$ She was the first woman to be executed following a trial before the Southern Circuit Court since 
Katherine McKinnel had been executed for child murder in Dumfries in 1758. The Caledonian Mercury observed that the unusual circumstance of the execution of a female in this part of Scotland excited the public's curiosity and attracted an immense crowd. ${ }^{66}$

Compared to other property offences, the crime of robbery stood out in that, by its very definition, it included either the use or threat of violence. In terms of female involvement in the commission of the crime, King and Beattie have respectively demonstrated that English women were rarely brought before the courts for property offences that involved the use of violence. ${ }^{67}$ In comparison, Kilday found that, of the total indictments relating to the crime of robbery brought before the Justiciary Court in Lowland Scotland, women were involved in 35\% of the cases. ${ }^{68}$ This would suggest that they would make up a sizeable proportion of the offenders capitally convicted for the crime. However, this was not the case. The reason for this likely lies in the fact that Kilday found that around half of the women were also indicted as 'resetters', who would pass on the stolen goods, and in three quarters of the total cases they were also charged with assault. ${ }^{69}$ Therefore, it is probable that most of these women were convicted of either assault or reset of theft which were lesser crimes than robbery itself and did not carry a capital punishment.

Isabella McMenemy was the only Scottish woman executed for robbery throughout the period under investigation here. Indeed, hers was the only example of a women executed for a property offence that involved any real degree of violence against the person. She suffered the last punishment of the law along with her husband Thomas Connor in Glasgow. The court heard how she acted as a decoy to lure a boatman on the banks of Paisley canal by the name of Mckinnon into a secluded area so Thomas could beat him with a stone "to the great effusion of his blood." They then proceeded to rob him of 40 shillings in silver. When passing the death sentence for both, Lord Meadowbank stated with consternation that the female offender had been the principal actor in devising the robbery. ${ }^{70}$ Beattie argued that when women did engage in robberies it was often with male accomplices, for whom they acted as decoys and for this reason there may have been numerous women never taken or prosecuted for their part in the crime. ${ }^{71}$ In Isabella's case it was her role as the decoy, and apparent deviser of the robbery, that the presiding judge found to be of deepest concern and arguably sealed her fate and prevented her from receiving the Royal mercy. An article in the 
Aberdeen Journal lamented that it had been "necessary to inflict the punishment of death on a woman" but added that it was fortunately a rare occurrence. ${ }^{72}$

In the period between 1740 and 1834, over 1,000 Scottish women received some form of punishment for a property crime by the central criminal courts. Of this number, some of the women had committed petty thefts but many had committed thefts or theft with housebreaking that could have potentially led to a capital conviction. However, as previous chapters have demonstrated, the distinct practice of the Scottish courts in allowing the libel to be restricted to an 'arbitrary punishment' in potentially capital cases was crucial in offering the courts different penal options to punish property offenders. The overwhelming majority of women convicted for a property offence were either transported, banished from Scotland, or imprisoned and a small number were given corporal punishments such as whipping or standing upon the pillory. In the second half of the eighteenth century, there were a few cases where the courts wanted to inflict a harsher punishment and thus they ordered that the criminals be whipped or pilloried prior to being banished or transported. However, the eighteenth- and early nineteenth-century Scottish central court judges passed the death sentence in less than $1 \%$ of the total number of cases where women received some form of punishment for a property offence. In the cases of Margaret Crossan and Isabella McMenemy there were evident aggravations that led them to the gallows. However, when attempting to gain an understanding of the factors that led the remaining nine Scottish women to the scaffold for theft or theft and housebreaking, two key areas must be explored: the importance of repeat offences and the chronology of the executions.

In six of the nine cases the courts heard how the women were repeat offenders. In four of these cases the women had illegally returned from previous sentences of banishment from Scotland for earlier property crimes. For example, Elizabeth Paul was first tried in Glasgow in 1778 for theft from a bleachfield. She had petitioned the court and was banished from Scotland for life. ${ }^{73}$ She was apprehended for the same crime and again brought before the Glasgow Circuit Court in 1782. This time she was sentenced to be whipped through the streets of the city before she was again banished from Scotland for life. ${ }^{74}$ On her third appearance before the court for the crime she had stolen four pieces of cloth valued at $£ 6$ 6s. This time the judges ordered that she be executed in October $1786 .{ }^{75}$ Within the Scottish court records, if an offender was described 
as a 'habute' or 'repute' thief, this could prompt the courts to make an example of them, as in cases where women had returned from banishment and had continued in their criminal ways. However, it is the argument here that this alone did not always send them to the scaffold. Instead, the chronology of the cases was a crucial factor in sealing their fate.

Of the total 11 cases of women executed for a property offence, six had occurred between 1780 and 1786. Chapter 3 demonstrated that the period between the outbreak of the American War of Independence and the establishment of Botany Bay as an alternative destination for British convicts was a peak period in Scotland's use of capital punishment. The removal of the penal option of transportation was a key factor that led the courts to pass the death sentence against a greater number of criminals, including women. A total of 18 women were capitally convicted for a property offence in the 1780s, of whom six were executed and 12 were pardoned. In this respect, Scotland's use of the death sentence against women was comparable to the situation in England. Beattie stated that between 1783 and 1787,12 women were capitally convicted in Surrey, of whom eight were executed. This rate of execution was striking as no women had been executed in Surrey in the previous 20 years. ${ }^{76}$

Following the capital conviction of Jean Lindsay and Henrietta Faulds for theft in 1784, petitions sent from Glasgow stated that thousands of its inhabitants wished for the extension of mercy and begged for the assistance of the Lord Advocate in securing a pardon. ${ }^{77}$ Despite their efforts Jean was executed. As Henrietta claimed she was pregnant her sentence was delayed for a sufficient time to secure her a pardon on condition of banishment. Similar efforts were made, but failed, to secure a pardon for Jean Craig, whose case was detailed in the discussion of the 1780s as a peak period of executions in Chap. 3. Therefore, this study of the women capitally convicted in the 1780s supports the argument made in Chap. 3, namely that there was not a great public desire, especially at a local level, to send all criminals convicted of capital crimes to the scaffold. Those that did meet their end on the gallows arrived there, for the most part, due to a combination of the difficulties facing the courts in sentencing suitably harsh alternatives and the fact that four of the six women were repeat offenders.

\section{Conclusion}

To conclude, this chapter has demonstrated that there were a range of penal options available to the eighteenth- and early nineteenth-century Scottish courts when dealing with female criminals. The courts exercised 
a great degree of discretion when responding to the women brought before them as they did with male criminals. Across the period under investigation here, the death sentence accounted for only $4 \%$ of the punishments meted out to women. Although the figure fluctuated slightly and was higher in the mid-eighteenth century but lower in the early nineteenth century, there was very little appetite for sending women to the scaffold in Scotland. In this sense a study of the Scottish experience reinforces previous arguments made in relation to female criminality elsewhere in Britain. ${ }^{78}$ Despite this, the chapter has also explored the importance of Scotland's distinct court procedures when shaping its analysis of the implementation of capital punishment against women.

The crime of infanticide was a form of homicide punishable by death. However, only around $13 \%$ of the total offenders who were punished for the crime faced the death sentence. Therefore, this study does not support the argument that women received aggravated punishments. ${ }^{79}$ Instead, it has shown that murderous women were subject to the stipulations of the Murder Act, as were men, but there was less appetite to see women mount the scaffold for infanticide, particularly after the concentration of cases in the mid-eighteenth century. Despite the provisions of the 1690 statute not being formally repealed until 1809 , in practice judicial responses to infanticide and its punishment had undergone long and gradual processes of change. The courts increasingly utilised other penal options that fell short of the death sentence to punish the women convicted of child murder, notably banishment. The distinct Scottish practice of allowing offenders to petition the courts for banishment or transportation had a profound effect upon the country's use of capital punishment for child murder and for serious property offences. As discussed in Chap. 2, this meant that a large proportion of offenders brought before Scotland's central criminal courts faced a punishment, but ensured that the death sentence accounted for only a small proportion of cases. In terms of child murder, this penal option ensured that women faced some form of punishment at a time when juries often required more than the provisions of the statute to convict. In addition, only a very small proportion of the total women convicted of potentially capital property offences faced the hangman's noose. This chapter has demonstrated that, when women did suffer the last punishment of the law as a reward for their commission of crime, there were often discernible factors that had sealed their fate. 
In the cases of women who had murdered someone other than their child, the motive and method of killing were crucial in sending them to the gallows. In addition, an analysis of the 23 cases of child murder demonstrates that we must not view all the women as victims of circumstance who had acted solely through neglect. Instead, some of them showed as much premeditation and malice in their commission of the murders as in other male and female homicide cases, thus providing some reinforcement to Kilday's work. ${ }^{80}$ However, an overarching factor in many of the cases was the desire to conceal both their pregnancy and the birth of their infants. The locations at which the bodies were found as well as the methods of killing were heavily determined by these factors. In turn, these motivations were dwelled upon in the courts to secure convictions although, as the period progressed, these issues were more heavily debated upon. What is clear is that a study of the use of the death sentence against women enhances our understanding of how the Scottish experience can reinforce patterns evident in the wider British historiography. However, it cannot simply be assimilated into this body of work due to the distinctions of both the Scottish legal system and their judicial and popular responses to female criminality.

\section{Notes}

1. See Christopher A. Whatley, "Women and the Economic Transformation of Scotland c.1740-1830", Scottish Economic and Social History 14 (1994): 19-40; E. C. Sanderson, Women and Work in Eighteenth-Century Edinburgh (London: Palgrave, 1996).

2. Rosalind Mitchison and Leah Leneman, Sexuality and Social Control: Scotland 1660-1780 (Oxford: Blackwell, 1989); Rosalind Mitchison and Lean Leneman, Sin in the City: Sexuality and Social Control in Urban Scotland, 1660-1780 (Edinburgh: Scottish Cultural Press, 1998).

3. Lynn Abrams, Eleanor Gordon, Deborah Simonton and Eileen Janes Yeo (eds.), Gender in Scottish History since 1700 (Edinburgh: Edinburgh University Press, 2006).

4. For select publications offering substantial surveys of the Scottish experience of the witch trials, see Christina Larner, Enemies of God: The WitchHunt in Scotland (London: Chatto \& Windus, 1981); Julian Goodare, The Scottish Witch-Hunt in Context (Manchester: Manchester University Press, 2002); Brian P. Levack, Witch-Hunting in Scotland: Law, Politics and Religion (London: Routledge, 2007). 
5. Anne-Marie Kilday, Women and Violent Crime in Enlightenment Scotland (Suffolk: Boydell Press, 2007).

6. For a study of infanticide in the Early Modern period, see Deborah A. Symonds, Weep not for me: Women, Ballads, and Infanticide in Early Modern Scotland (University Park: Pennsylvania State University Press, 1997). For studies of eighteenth- and early nineteenth-century Scotland, see Anne-Marie Kilday, "Maternal Monsters: Murdering Mothers in South-West Scotland 1750-1815", in Twisted Sisters: Women, Crime and Deviance in Scotland since 1400, ed. by Yvonne Galloway Brown and Rona Ferguson, 156-179, East Lothian: Tuckwell Press, 2002. For a more recent extensive study of the crime, see Anne-Marie Kilday, A History of Infanticide in Britain c.1600 to the Present (Basingstoke: Palgrave Macmillan, 2013).

7. For the English figures, see J. M. Beattie, Crime and the Courts in England 1660-1800 (Oxford: Oxford University Press, 1986), 514; Peter King, Crime, Justice and Discretion in England 1740-1820 (Oxford: Oxford University Press, 2000), 280.

8. Garthine Walker, Crime, Gender and Social Order in Early Modern England (Cambridge: Cambridge University Press, 2003), 8.

9. Anne-Marie Kilday, "Contemplating the Evil Within: Examining Attitudes to Criminality in Scotland 1700-1840", in Crime, Courtrooms and the Public Sphere in Britain 1700-1850, ed. by David Lemmings, 147-166, 150, Farnham: Ashgate, 2012.

10. Note that this percentage is based upon the figures for the whole of Scotland across the period between 1740 and 1834 . When broken down further, the death sentence accounted for around $15 \%$ of the total punishments between 1740 and the 1780 s, but less than $2 \%$ between 1815 and 1834 when sentences of transportation and imprisonment increased significantly.

11. Kilday, Women and Violent Crime, 51.

12. The case is detailed in NAS JC7/30/30-67. Despite often being traditionally thought of as a male name, Nicholas was a fairly common Scottish female name, particularly in the lowlands, in the eighteenth and nineteenth centuries.

13. Caledonian Mercury, Thursday, 15 August, 1754, 3.

14. See Ruth Campbell, "The Sentence of Death by Burning for Women", The Journal of Legal History 5 (1984): 44-59; Simon Devereaux, "The Abolition of the Burning of Women in England Reconsidered", Crime, History and Societies 9 (2005): 73-98.

15. NAS JC11/63/52.

16. NAS JC8/5/70-90. 
17. Scots Magazine, Thursday, 1 January 1807, 75 .

18. NAS JC7/28/413-449. Note that surgeons told the court that the likely cause of death was suffocation.

19. Durham County Advertiser, Saturday, 22 March 1823, 2.

20. NAS JC8/17/49.

21. Kilday, Women and Violent Crime, 33, 56.

22. NAS JC12/8/5.

23. Caledonian Mercury, Monday, 11 October 1830, 3.

24. Kilday, Women and Violent Crime, 56.

25. NAS JC11 $/ 24 / 328$.

26. NAS JC1 $1 / 24 / 328-351$.

27. NAS JC7/38/219.

28. NAS JC7/38/219-43.

29. Peter King, "Making Crime News: Newspapers, Violent Crime and the Selective Reporting of Old Bailey Trials in the Late Eighteenth Century", Crime, History and Societies 13 (2009): 91-116, 107.

30. For select examples, see R. W. Malcolmson, "Infanticide in the Eighteenth Century", in Crime in England 1550-1800, ed. by J. S. Cockburn, 187209, London: Methven, 1977; Lionel Rose, Massacre of the Innocents: Infanticide in Great Britain 1800-1939 (London: Routledge, 1986). For more recent studies see Mark Jackson (ed), Infanticide: Historical Perspectives on Child Murder and Concealment 1550-2000 (Aldershot: Ashgate, 2002); Josephine McDonagh, Child Murder and British Culture 1720-1900 (Cambridge: Cambridge University Press, 2003); Kilday, $A$ History of Infanticide. For specific Scottish examples see Symonds, Weep not for me; Kilday, Women and Violent crime, 59-79.

31. Symonds, Weep not for me, 5 .

32. Mark Jackson, Newborn Child Murder: Women, Illegitimacy, and the Courts in Eighteenth-Century England (Manchester: Manchester University Press, 1996), 29-51.

33. Anne-Marie Kilday, "Desperate Measures or Cruel Intentions? Infanticide in Britain since 1600", in Histories of Crime: Britain 1600-2000, ed. by Anne-Marie Kilday and David Nash, 60-79, 69, Basingstoke: Palgrave, 2010.

34. NAS JC11/23/220-222.

35. Symonds, Weep not for me, 2.

36. Lean Leneman and Rosalind Mitchison, "Scottish Illegitimacy in the Early Modern Period", Economic History Review 40 (1987): 41-63, 41.

37. NAS JC7/39/327-351.

38. Caledonian Mercury, Thursday, 23 May 1793, 3.

39. Scots Magazine, Sunday, 1 October 1749, 45.

40. NAS JC8/5/177. 
41. Saunders News-Letter, Wednesday, 13 January 1808, 2.

42. Scots Magazine, Monday, I February 1808, 77.

43. In his recent study of homicide in eighteenth-century Scotland, Knox similarly found that an overwhelming proportion of victims in child murder cases were newborns. See W. W. J. Knox, with the assistance of L. Thomas, "Homicide in Eighteenth-Century Scotland: Numbers and Theories", The Scottish Historical Review 94 (2015): 48-73, 54.

44. Across this period there were very few married women charged with the murder of their children. This is not to say that married women did not murder their children, but their absence in the court records was likely due to the removal of concealment as a motive, due to contemporary beliefs that married women would have no need to conceal their pregnancy or the birth. Thus, the death of legitimate children would have more likely been deemed of natural, as opposed to suspicious, causes. In addition, of the very small number of married women who were charged with the crime, in the few cases where they were found guilty, they were often determined to have been suffering temporary insanity at the time and released into the care of their husbands.

45. NAS JC13/16/55-65.

46. James Cleland, The Annals of Glasgow, Comprising an Account of the Public Buildings, Charities and the Rise and Progress of the City (Glasgow: John Smith and Son, 1829), 513.

47. Kilday, Women and Violent Crime, 60.

48. Kilday, Women and Violent Crime, 67. In her analysis of 140 indictments for infanticide, Kilday found that in $63 \%$ of the cases blood was shed, namely through stabbing and/or battering to death.

49. NAS JC7 $/ 32 / 217$.

50. NAS JCl1/23/76-88.

51. NAS JC11/18/258-259.

52. NAS JC11/17/143.

53. See Malcolmson, "Infanticide in the Eighteenth Century", 188, 195; James Kelly, "Infanticide in Eighteenth-Century Ireland", Irish Economic and Social History 18 (1992): 5-26, 18.

54. In some cases where women had claimed that their infants had been born dead, a surgeon removed the lungs to conduct tests to see if they would float. It was believed that this would indicate if the child had taken a breath.

55. Lean Leneman and Rosalind Mitchison, "Scottish Illegitimacy Ratios in the Early Modern Period", The Economic History Review 40 (1987): $41-63,53,58$.

56. Kilday, A History of Infanticide, 29-30.

57. Scots Magazine, Monday, 3 May 1762, 52. 
58. Kilday, “Contemplating the Evil Within”, 150.

59. In her study of infanticide, Kilday found a similar increase in petitions for banishment alongside a decline in capital convictions for the crime. See Kilday, A History of Infanticide, 30.

60. NAS JC7/23/341.

61. NAS JC7/30/23.

62. NAS JC11/44/76.

63. The Laws Respecting Women, as they Regard their Natural Rights, or their Connections and Conduct (London: 1777), 307.

64. King, Crime, Justice and Discretion, 280.

65. NAS JC12/31/1-6.

66. Caledonian Mercury, Monday, 20 October 1817, 3.

67. King, Crime, Justice and Discretion, 196; Beattie, Crime and the Courts, 238.

68. Kilday, Women and Violent Crime, 132.

69. Kilday, Women and Violent Crime, 132-139. Kilday's suggestion that female robbers could suffer dismemberment of limbs prior to execution, gibbeting and post-mortem dissection is not substantiated by this research. Four men had a hand severed prior to execution, all for the crime of murder, and their cases are discussed in Chap. 5. In addition, this study has found that the only offence for which women received any form of post-mortem punishment was murder, as per the stipulations of the Murder Act.

70. NAS JC13/56/12; Morning Chronicle, Monday, 22 September 1828, 4.

71. J. M. Beattie, "The Criminality of Women in Eighteenth-Century England", Journal of Social History 8 (1975): 80-116, 90.

72. Aberdeen Journal, Wednesday, 29 October 1828, 4.

73. NAS JC13/22/31.

74. NAS JC13/23/115.

75. NAS JC13/26/85.

76. Beattie, Crime and the Courts, 584 .

77. TNA HOl02/50/126; HOl02/50/131.

78. Beattie, Crime and the Courts, 514; King, Crime, Justice and Discretion, 280.

79. Kilday, “Contemplating the Evil Within”, 150.

80. Kilday, Women and Violent Crime. For Kilday's analysis of the women who committed homicide and infanticide, see Chaps. 3 and 4 of the work. 
Open Access This chapter is licensed under the terms of the Creative Commons Attribution 4.0 International License (http://creativecommons.org/licenses/ by $/ 4.0 /$ ), which permits use, sharing, adaptation, distribution and reproduction in any medium or format, as long as you give appropriate credit to the original author(s) and the source, provide a link to the Creative Commons license and indicate if changes were made.

The images or other third party material in this chapter are included in the chapter's Creative Commons license, unless indicated otherwise in a credit line to the material. If material is not included in the chapter's Creative Commons license and your intended use is not permitted by statutory regulation or exceeds the permitted use, you will need to obtain permission directly from the copyright holder.

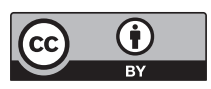

